\title{
Growing in Wisdom
}

Jennifer Bartholomew, Sacred Heart Seminary and School of Theology

ABSTRACT Inspired by the phrase "Growing In Wisdom," which was part of a phrase in the Atla organizational ends from 2016 to 2020 , this Listen and Learn presentation looks at a project that was to partner library staff with faculty to promote information literacy as it related to integrating work in theological education. What role does wisdom play in denominational guidelines and accrediting standards? Integrating Work in Theological Education, edited by Kathleen A. Cahalan, Edward Foley, and Gordon S. Mikoski (2017), describes the importance of both theory and practice in preparing students for ministry. What is the role of the library in integrating work? How can the library be a partner with faculty in theological education?

Good Afternoon. Thank you for joining me for this Listen and Learn session on "Growing in Wisdom." I am presenting from Milwaukee County, Wisconsin, where I live and work on traditional Potawatomi, Ho-Chunk, and Menominee homelands along the southwest shores of Michigami (Big Lake), part of North America's largest system of freshwater lakes, where the Milwaukee, Menominee, and Kinnickinnic rivers meet and the people of Wisconsin's sovereign Anishinaabe, Ho-Chunk, Menominee, Oneida, and Mohican nations remain present.

This project grew out of a desire to have the library become a more active partner with faculty in theological education and a book of essays on Integrating Work in Theological Education. How can we more fully serve our students and faculty?

From 2016 to 2020, the following quote was Atla organizational end 3.0: "Students, scholars, and religious leaders skillfully use information resources to create knowledge, grow in wisdom, and share the results of their research.” This end was created with transformation in mind. How does theological education, and how does our library, help people to grow in wisdom?

When I think about wisdom in theological education and in the context of the library, I look to the teaching of our sacred texts, the 
guidance our faith offers, the mission statement of my school, and standards from our accrediting bodies.

My particular context is a Catholic seminary, run by the Priests of the Sacred Heart for our own seminarians. We educate seminarians for the Archdiocese of Milwaukee. The Program for Priestly Formation, fifth edition - the guide used for Catholic theological education in the United States (www.usccb.org/upload/programpriestly-formation-fifth-edition.pdf)—mentions the importance of wisdom, especially practical wisdom, as it relates to preaching the Gospel, and for continued attention to "formation," which values life-long learning.

What tradition do you represent or most identify with?

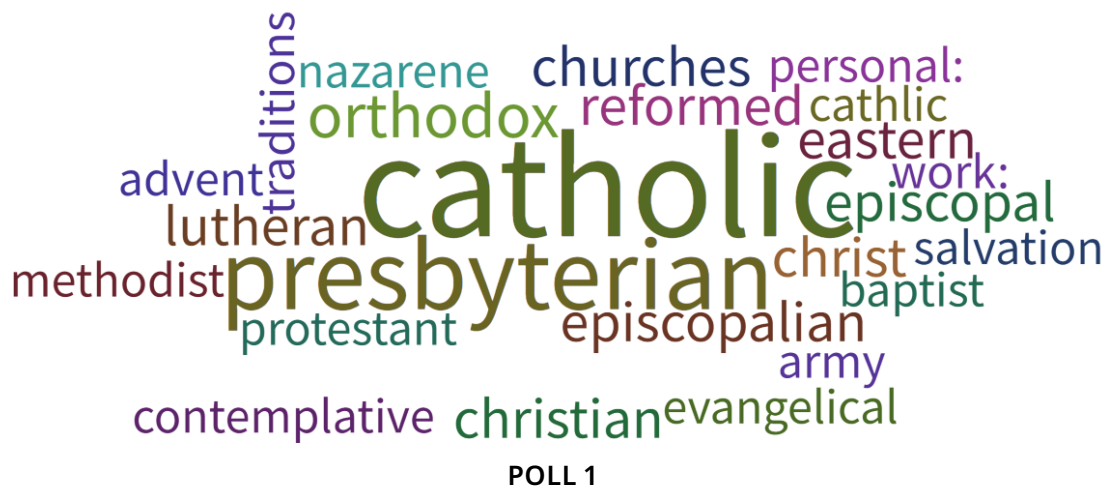

The new ATS standard for libraries (www.ats.edu/accrediting/overview-accrediting/redevelopment-ats-commission-standards-andprocedures) calls for theological schools to "be communities of faith and learning, grounded in the historical resources of the tradition, the scholarship of the academic disciplines and the wisdom of communities of practice...” They go on to say that theological libraries are curated collections and instructional centers with librarians guiding research and organizing access to appropriate resources. Libraries and librarians partner with faculty in student learning and formation to serve schools' educational missions and to equip students to be effective and ethical users of information resources.

Through conversations with our academic dean, I know that one way wisdom is fostered at Sacred Heart is through integrative thinking. The word integrate or integrative is mentioned 25 times in the 
ATS standards that were in place until June 2020. Our current curriculum addresses integrative thinking in several ways, depending upon the degree program and pathway. For MDiv students, this occurs in a three-semester sequence. Students first write a summarylevel reflection paper on a ministerial incident. The next semester, they work on a longer case study of a ministerial incident. During their final semester, they present the case study to a small group of faculty and students. The students seek to understand the incident more deeply through a look at resources in scripture, church history, systematic theology, and pastoral care. As they research and reflect, they understand their motivations and responses more clearly. This process gives them the tools to respond more effectively the next time they are faced with a challenge.

\section{What kind of experience in community has helped}

\section{you grow in wisdom? e.g., coaching, leading, serving on a board, volunteer work}

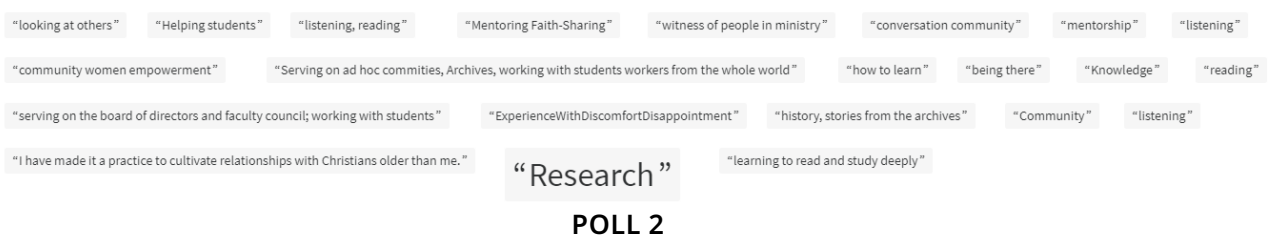

I came across this book on integration soon after it was publishedIntegrating Work in Theological Education, edited by Kathleen A. Cahalan, Edward Foley, and Gordon S. Mikoski (Eugene, OR: Pickwick Publications, 2017). The twenty essays on schools, curriculums, courses, and frameworks by authors from a variety of Christian denominations has informed, influenced, and inspired me. The issues raised point to the challenge and complexity of preparation for ministry. You can't learn how to minister without the presence and support of a community. The library is part of the community and can be a valued partner for students and faculty.

Edward Foley, of Catholic Theological Union in Chicago, says integration is the combination of head, hand, and heart, when orthodoxy (right believing), orthopraxy (right acting), and orthopathy (right feeling) come together (Cahalan 2017, 5). Chris Scharen and 
Eileen Campbell, who partnered on "Learning Pastoral Imagination: A Five-Year Report on How New Ministers Learn in Practice," say that "integrative and embodied learning happened when these three characteristics were present: an experience of the clash of abstract, decontextualized knowledge with lived situations, a sense of overwhelming which comes from dealing with multiple variables in these situations, and a sense of responsibility for the risk entailed in choosing a course of action" (Cahalan 2017, 5-6).

There are multiple frameworks for integrating work. Some of the elements involved are: bridging the gulf between areas of theological study (Bible, ethics, theology) and other disciplines (pastoral care, neuroscience), making connections between bodies of knowledge, and finding ways to overcome the divide between theory and practice (Cahalan 2017, 3-4).

As students begin integrative work, how can the theological library provide support? We provide access to digital and print resources. We offer programming. Our services include teaching a course on research and writing and providing research and technology assistance. We can do more if we partner with faculty. Information literacy has created a way for librarians to foster integrative thinking skills through curriculum development and instruction. The ALA's Information Literacy Framework (www.ala.org/acrl/standards/ ilframework) offers many opportunities for students to acquire new skills as they progress in their studies. We support student learning in many ways, but we do not teach information literacy skills often enough. My hope for this project was to partner with faculty, choose an assignment, and teach skills that would enhance integrative learning.

This year I started small, having conversations with a few of our professors. The most fruitful project was working with our homiletics professor-a Catholic deacon with 25 years of preaching experience. We looked at the syllabus, listened to student ferverinos (a short reflection on a gospel reading), gave feedback, and created a rubric that captured elements of the literacy framework that best pertain to the complexity of preaching. Then, in March, Covid-19 disrupted the semester. Time for special projects and meetings disappeared as we transitioned to online learning. The library staff was asked to help the faculty transition their classes and then provide support for initiatives led by the academic dean for the rest of the semester. Next fall, we will use a hybrid model that allows us to be either in the 
classroom or online-a potential toggle response, depending on how Covid-19 is trending. I still have great hopes for this project. I hope that, in the next year, once we are more comfortable with online and hybrid learning, we can continue.

In his April column, our current Atla board president, Stephen Sweeney, reminded us of the role of libraries as community hubs and also of the important difference between physical distancing and social distancing in this time of pandemic. What does this mean for theological education? How will we adapt?

What networks do you belong to that have helped you to grow in wisdom? Your seminary or school of theology, church, small groups of friends? A group that has influenced me is non-academic. The Jewels are a group of about a dozen women who represent Christian, Muslim, Bahá'í, and Jewish faiths. We meet monthly to discuss a wide variety of issues. Over the past year, we've talked about many issues from a faith perspective. We share our traditions' teaching and we learn about others-what we hold in common, how we differ.

Mary Plaster (www.maryplaster.com), an artist from Duluth, Minnesota and a proponent of Sacred Art Activism, wrote an icon of Sophia (Lady Wisdom) - a figure from Judaic and Christian traditions. In Plaster's view, wisdom is not static; wisdom is specific to time and place. "I depicted Lady Wisdom seated in the context of the entire Cosmos, beckoning us to inclusive and sustainable decision-making that gently cooperates with global community. Ageless, androgynous, indigenous and totally unconcerned with material wealth and hierarchy, She insists on a new way of thinking that can potentially turn the world as we know it upside down."

Robert Kegan, cognitive psychologist, says, “To create new understandings, existing structures of knowledge must be dismantled, reconceived, and disembarked and new configurations established ...Learning entails integrating and disintegrating momentums as part of the creative dynamic of human development, knowing, and learning" (Cahalan 2017, 9).

This quote speaks to current events (e.g., the Covid-19 pandemic, antiracism protests) and the continuing work we are called to. Does theological education lead to integrative thinking, lead to wisdom? Will this make a difference? I'd like to share, in closing, these words from Bishop Mariann Edgar Budde, writing about the Diocese of Washington where she was called nine years ago. "Still, we are all being called to a deeper commitment now. There is much discern- 
ing, prayerful work to be done. Thanks to all who are rising to meet this moment with faith, hope, and love" (Budde, "Called to Go Deeper,” June 4, 2020, www.edow.org/about/bishop-mariann/writings/2020/06/04/called-go-deeper).

For those of us who are committed to theological education and libraries, this discerning work is ours too. We are a unique entity: part collections, part service-a dynamic agglomeration of instruction, assistance, and programming; a meeting place for community, where connections can be made, where new voices can be heard, where deep listening and engagement can happen. You are wise and your work is important. Let us find new ways to engage, serve, and transform.

Type in some words you associate with wisdom (one word at a time, answer as many times as you'd like)

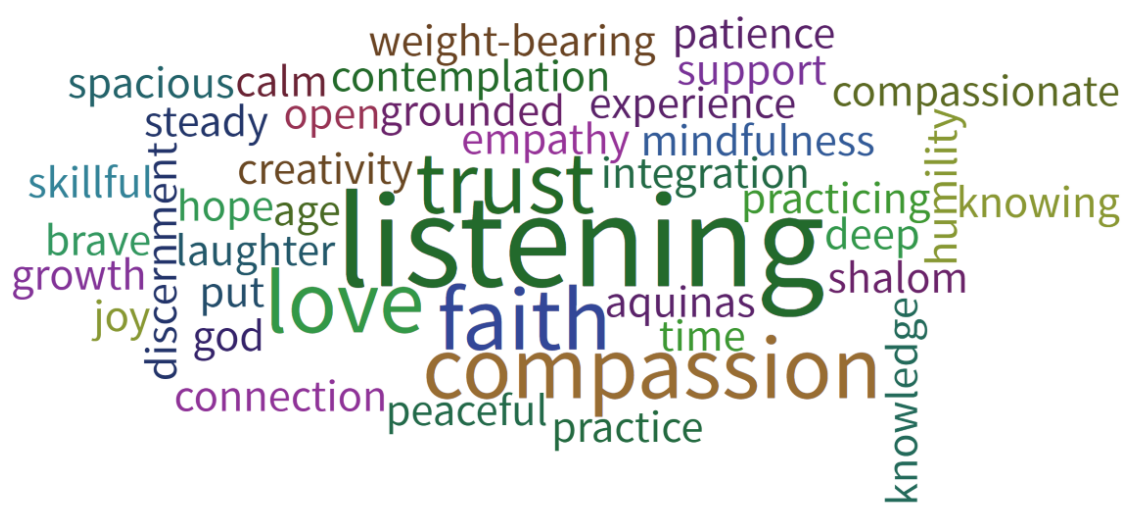

POLL 3 